\title{
Precision and accuracy of streamflow measurements in headwater streams during baseflow
}

\section{Precisão e acurácia de medições de vazão em rios de cabeceira durante o escoamento de base}

\author{
Camyla Innocente dos Santos ${ }^{1}$ (D), Pedro Luiz Borges Chaffe ${ }^{1}$ (D), Alondra Beatriz Alvarez Perez ${ }^{1}$ (D), \\ Pedro Ferreira Arienti ${ }^{1}$ (D) \& João Henrique Macedo Sá ${ }^{1}$ \\ ${ }^{1}$ Universidade Federal de Santa Catarina, Florianópolis, SC, Brasil \\ E-mails: camylainnocente@gmail.com (CIS),pedro.chaffe@ufsc.br(PLBC), alondrabaperez@gmail.com (ABAP), \\ pedro.arienti@posgrad.ufsc.br (PFA), jhenriquemsa@hotmail.com (JHMS)
}

Received: August 27, 2020 - Revised: December 21, 2020 - Accepted: January 18, 2021

\begin{abstract}
The quantification of baseflow is key for water resources management. However, there are few reports on the precision and accuracy in low streamflow measurements. In this paper, we systematically analyze the precision and accuracy of dilution streamflow measurements in headwater channels during baseflow. Precision refers to the variability of the values for repeated measurements and accuracy is how much the measured value approximates the reference one. We measured streamflow in 31 different cross-sections with contributing areas ranging from 0.02 to $5.33 \mathrm{~km}^{2}$. Streamflow measurements with the current meter were adopted as reference for accuracy estimation. A precision error of $\pm 5.0 \%$ was found for the measurements. The percent errors compared to reference streamflow ranged from 0.7 to $45.6 \%$, with a median of $6.1 \%$. Precision and accuracy are in the same order of magnitude found in the literature for larger streams. These results can be used for constraining the uncertainty of streamflow measurements and rainfallrunoff modeling of headwater streams.
\end{abstract}

Keywords: Hydrometry; Dilution method; Baseflow; Headwater streams.

\section{RESUMO}

A quantificação do escoamento de base é fundamental para a gestão dos recursos hídricos. No entanto, existem poucos estudos sobre a precisão e acurácia de medições de baixas vazões. Neste artigo, analisamos sistematicamente a precisão e a acurácia das medições de vazão feitas com o método de diluição em rios de cabeceira durante o escoamento de base. A precisão se refere à variabilidade dos valores das medições repetidas e a acurácia é o quanto o valor medido se aproxima de um valor de referência. Medimos a vazão em 31 diferentes seções transversais com bacias variando de 0,02 a $5,33 \mathrm{~km}^{2}$. As medições de vazão feitas utilizando o molinete foram adotadas como referência para estimativa da acurácia. Um erro de precisão de $\pm 5,0 \%$ foi encontrado para as medições. Os erros percentuais em relação a vazão de referência variaram de 0,7 a 45,6\%, com mediana de 6,1\%. Precisão e acurácia estão na mesma ordem de magnitude encontrada na literatura para vazões maiores. Esses resultados podem ser usados para restringir a incerteza das medições de vazão e na modelagem chuva-vazão em cabeceiras.

Palavras-chave: Hidrometria; Método de diluição; Escoamento de base; Rios de cabeceira. 


\section{INTRODUCTION}

Streamflow from headwater is used for drinking water, irrigation, and recreation (Freeman et al., 2007). Headwater streams control a large part of streamflow generation (Sidle et al., 2000) and they remove more nutrients than big streams (Alexander et al., 2000). Most of the time the water that flows in these streams is baseflow, coming from water stored in the soil and rock profiles (Egusa et al., 2016). The baseflow is of ecological importance since some chemical elements important for the biota are better fixed in low flow conditions (Doyle et al., 2005) and it acts as a buffer for changes caused by climate and land use (Van Loon et al., 2012). Therefore, the quantification of the water stored and released as baseflow is key for water resources management (Miller et al., 2016) as well as for the understanding of runoff generation processes in watersheds (e.g. Egusa et al., 2019; Uchida \& Asano, 2010).

There are three main methods to measure streamflow in natural channels: the velocity-area method; the dilution method; and the use of hydraulic structures such as weirs or flumes (Kondolf \& Piégay, 2016). The most common procedure for measuring streamflow is to calculate the average velocity in a crosssection using a current meter along the stream width and depth profile (McMillan et al., 2012). The main types of instruments of the current meter are mechanical (rotations of a propeller) or acoustical (ADCP - acoustic Doppler current profiler). However, it requires a cross-section where the water depth is sufficient for the equipment to work. The use of weirs or flumes requires ad hoc hydraulic works. The dilution method is particularly effective for small streams with irregular channel cross-sections (Bergstrom et al., 2016), its only requirement being that the tracer should be completely mixed with the flow.

Quantifying streamflow measurement errors is crucial as they will be directly translated into uncertainty in hydrologic models (McMillan et al., 2010) and may lead to unnecessary costs due to poor ecological or social decisions (McMillan et al., 2017). Two types of errors in data measurement can be listed: errors related to precision and errors related to accuracy. Precision refers to the variability of the values found for repeated measurements (Day, 1976), which is a measure of "the statistical variance of an estimation procedure" (West, 1999). Accuracy is how much the measured value approximates a reference taken as the correct value (Walther \& Moore, 2005).

Streamflow measurement in headwaters is challenging as the channels are usually highly heterogeneous with exposed bedrock, woody debris, cascades, and step-pools (Montgomery \& Dietrich, 1989). Even for large-scale rivers, where cross-sections are generally uniform, there is still a lack of information on the expected distributions and magnitudes of error in streamflow observational data (McMillan et al., 2012). Most streamflow measurement errors were estimated for rivers with streamflow in the orders of $10^{2}$ to $10^{5} \mathrm{~L} \mathrm{~s}^{-1}$ (e.g. Benischke \& Harum, 1990; Clow \& Fleming, 2008; Day, 1976, 1977; Kite, 1993), while little is known for headwater rivers on the order of $10^{-1}$ to $10^{2} \mathrm{~L} \mathrm{~s}^{-1}$ (e.g. Bjerve \& Grøterud, 1980; Hudson \& Fraser, 2002).

The accuracy is generally estimated by comparing different measurement techniques (e.g. Benischke \& Harum, 1990; Bjerve \& Grøterud, 1980; Davids et al., 2019; Gees, 1990; Kite, 1989). Most of the time in headwater streams is not possible to use different techniques in the same cross-section. To overcome a such challenge one can resort to flow scaling, because streamflow is usually linearly related to the drainage area (Asano \& Uchida, 2010; Egusa et al., 2016; Karlsen et al., 2016; Peralta-Tapia et al., 2015; Uchida \& Asano, 2010; Woods et al., 1995) and velocity is a power-law function of streamflow (D'Angelo et al., 1993; Edwardson et al., 2003; Leopold, 1953; Morrice et al., 1997; Wondzell et al., 2007).

In this paper, we systematically analyze the precision and accuracy of streamflow measurements in headwater channels under baseflow conditions. We used field data of first to fourth order catchments with areas ranging from 0.02 to $5.33 \mathrm{~km}^{2}$. Measurement errors were estimated using three analyses: (i) the variance of repeated measurements; (ii) the comparison between the streamflow measured using the dilution method and the current meter and; (iii) the errors in relation to the rating curve. In addition, we looked at the relationships between streamflow, drainage area and flow velocity in our data and compared the results with those found in the literature.

\section{MATERIALS AND METHODS}

\section{Study area}

The Peri Lake Watershed is located on Santa Catarina Island, southern Brazil (Figure 1a). Peri Lake is the largest source of water supply on the island. It is an important ecosystem for biodiversity preservation (Sbroglia \& Beltrame, 2012) and in 1981 it was established as a Municipal Conservation Area. The $20 \mathrm{~km}^{2}$ watershed is surrounded by hillslopes covered with Atlantic rainforest remains and by vegetated sand banks (restinga) that separate the $5.7 \mathrm{~km}^{2}$ coastal lake from the sea (Figure 1b). It is located in the transition between tropical and temperate climates, the average annual precipitation is $1500 \mathrm{~mm}$, with hot summers and no dry season. The geological formation of the Peri Lake Watershed is granite and dykes in practically its entire structure, with some sedimentary deposits at lower altitudes (Figure 1c) (Universidade Federal de Santa Catarina, 2018).

Streamflow measurements were made at 31 different crosssections of the Peri Lake Watershed (Figure 1d). There are four main alluvial channel-reach morphologies (Figure 1e) which were classified according to Montgomery \& Buffington (1997). There are 6 alluvial cross-sections in first order streams near the springs. Cascade is the most common channel-reach morphology ( 22 cross-sections) with drainage areas ranging from 0.13 to $1.13 \mathrm{~km}^{2}$ in streams of first to third order. Three cross-sections can be classified as steppool. Streams characterized by cascade and step-pool turned into dune ripple near Peri Lake (points 4, 8 and 10 in Figure 1d), they are associated with alluvial deposits (Figure 1c) and low gradient sand channels (Montgomery \& Buffington, 1997).

\section{Streamflow measurements}

Streamflow was measured using three different methods, depending on the cross-section: the volumetric method, the current meter, and the dilution method. The monitoring occurred on 
(a)

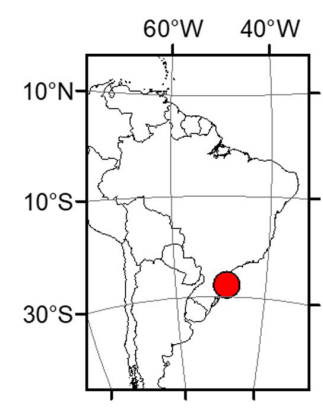

(b)

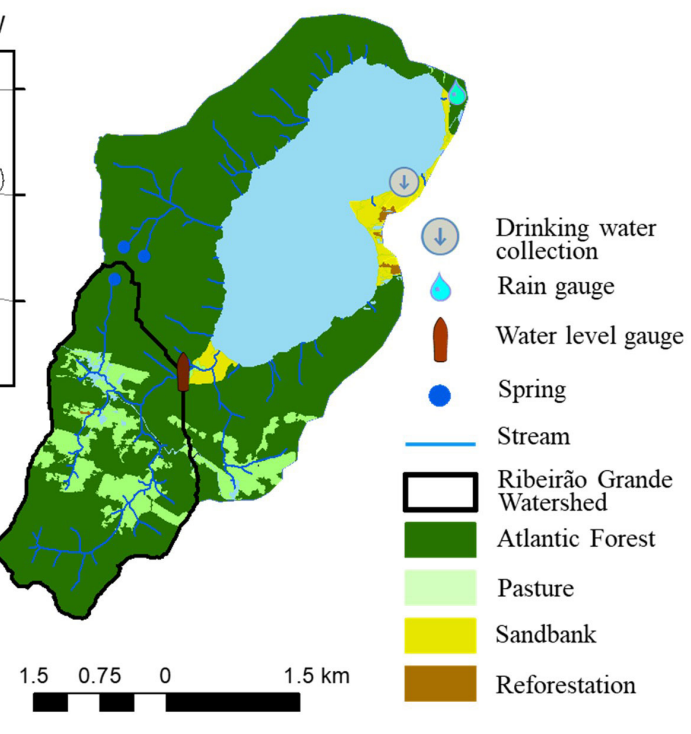

(c)

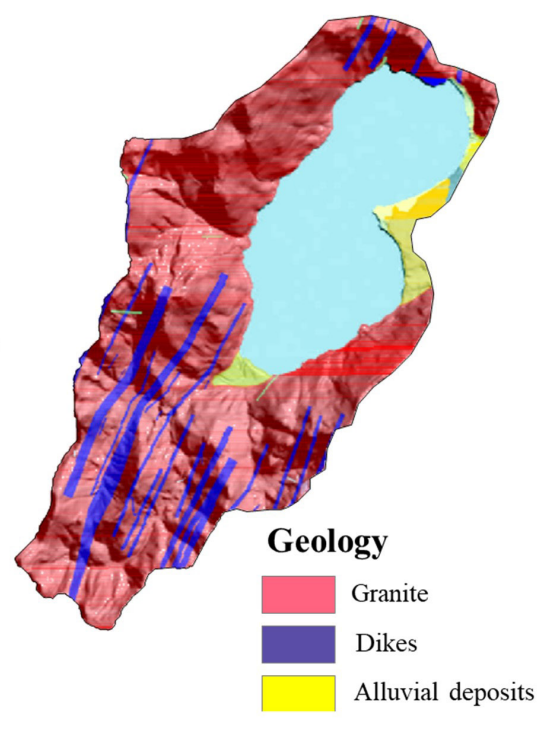

(d)

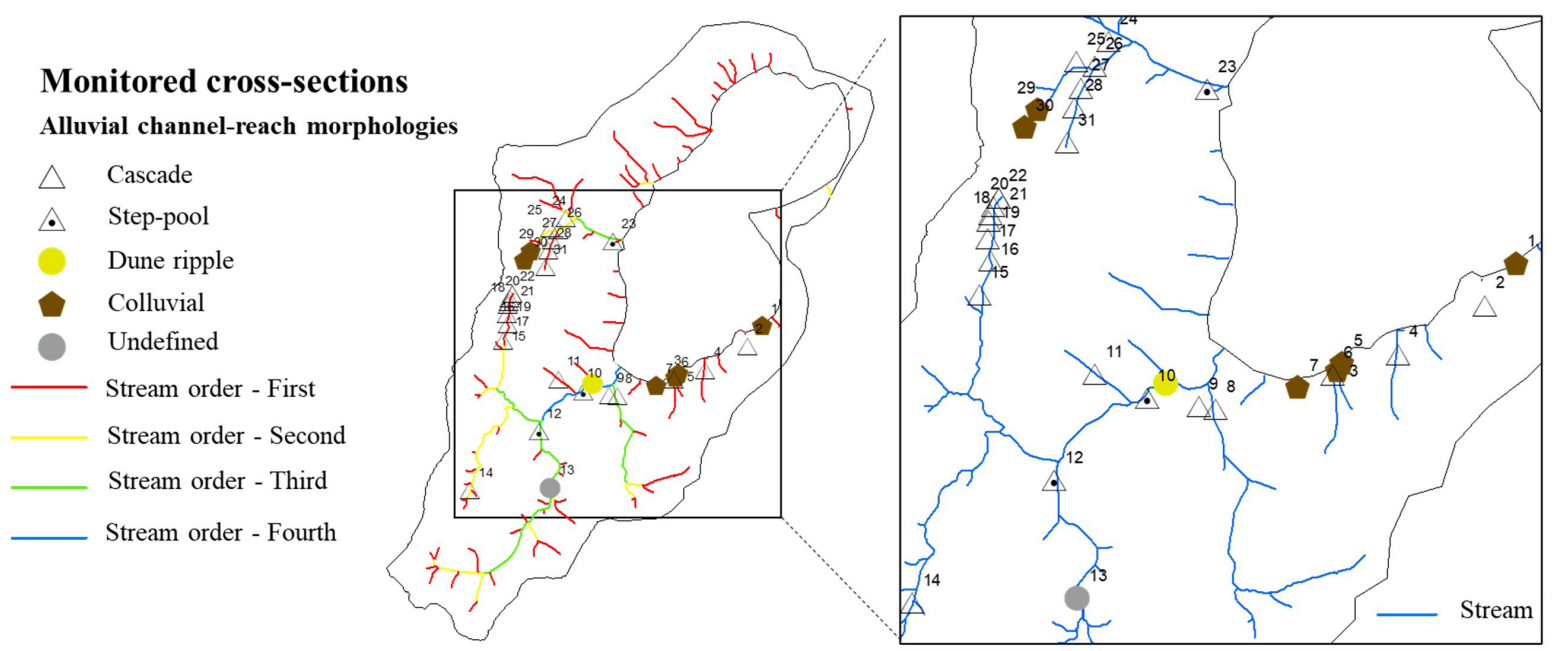

(e)

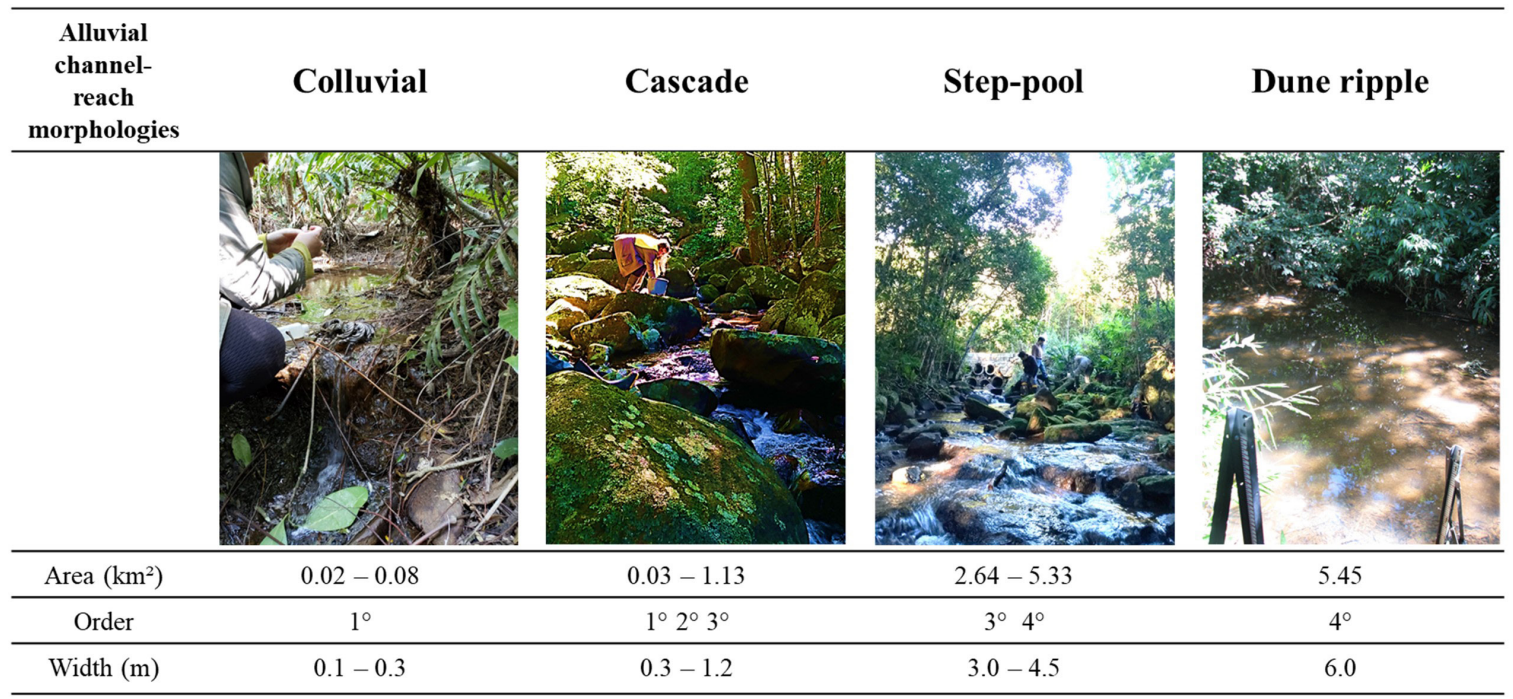

Figure 1. The Peri Lake Watershed: (a) Location in southern Brazil; (b) Land cover map; (c) Geology (Universidade Federal de Santa Catarina, 2018); (d) Drainage network and monitored cross-sections; (e) Drainage channel classification. 
17 different days (Table 1), during baseflow. We adopted one or more days without rainfall as baseflow conditions. Since the time of concentration of the largest contributing watershed is on the order of 1h (estimated using the formula of Dooge, 1973), we considered that after a day without rainfall there would be only baseflow in the stream.

For the volumetric method we used plastic containers with a volume of $0.25 \mathrm{~L}$ and $7 \mathrm{~L}$ (Figure $2 \mathrm{a}$ ). The streamflow was estimated according to the following equation:

$$
Q_{v}=\frac{V}{T}
$$

where $Q_{v}$ is streamflow by the volumetric method $\left[\mathrm{L} \mathrm{s}^{-1}\right], V$ is the collected volume [L] and $T$ is the total time of volume collection $[\mathrm{s}]$. The verification that all the water of the cross-section flowed into the container was done visually.

We used a mechanical current meter to estimate streamflow (Figure 2b). The total streamflow is approximated by measuring the width, depth, and velocity at discrete points along the channel cross-section. The total streamflow in a cross-section is given by:

$$
Q_{C M}=\sum_{i=1}^{n} \frac{A_{i} v_{i}}{1000}=\sum_{i=1}^{n} \frac{b_{i} d_{i} v_{i}}{1000}
$$

where $Q_{C M}$ is the streamflow $\left[\mathrm{L} \mathrm{s}^{-1}\right]$ obtained with the current meter; $n$ is the number of verticals $i$ across the channel; $A_{i}$ is the cross-sectional area $\left[\mathrm{m}^{2}\right] ; b_{i}$ is the width of the vertical $i[\mathrm{~m}]$; $d_{i}$ is the average depth of the vertical $i[\mathrm{~m}]$, and $v_{i}$ is the average downstream velocity in vertical $i\left[\mathrm{~m} \mathrm{~s}^{-1}\right]$. The width of the vertical is estimated as $\left(x_{i-1}+x_{i+1}\right) / 2$, where $x$ is the horizontal distance of the vertical from the edge of the water (Cohn et al., 2013). To estimate the average velocity at a vertical, velocity was measured at $60 \%$ of the height of the vertical, according to the method described in Santos et al. (2001).
According to Hudson \& Fraser (2002) there are four assumptions for the slug dilution method: (i) the salt must be completely mixed with the flow at the in-stream measurement point; (ii) the salt must be added to the channel instantaneously; (iii) there must be no local inflows between the injection and measurement points and; (iv) the measured reach should be straight with no pools where the salt can become retarded and separated from the main flow. We used table salt as a tracer for the dilution method. Salt concentration was measured using a conductivity probe (Figure 2c). The streamflow was calculated as:

$$
Q_{D}=\frac{V C t}{\sum_{0}^{\tau}\left(C r(\tau)-C r_{0}\right) d \tau}
$$

where $Q_{D}$ is the streamflow $\left[\mathrm{L} \mathrm{s}^{-1}\right]$ obtained with the dilution method, $V$ is the volume of tracer solution [L], Ct is the concentration of the applied salt solution $\left[\mathrm{g} \mathrm{L}^{-1}\right], \mathrm{Cr}(\tau)$ is the concentration of salt in the stream $\left[\mathrm{g} \mathrm{L}^{-1}\right]$ at time $\tau, C r_{0}$ is the concentration of salt in the stream $\left[\mathrm{g} \mathrm{L}^{-1}\right]$ at the time of salt injection, and $d \tau$ is the time step (here 5 seconds).

The flow velocity was estimated as:

$v_{D}=\frac{M l}{t_{i n}-t_{e}}$

where $v_{D}$ is the flow velocity $\left[\mathrm{m} \mathrm{s}^{-1}\right]$ obtained with the dilution method, $M l$ is the mixing length (distance along the stream between the point of salt injection and the location of the probe in the stream) $[\mathrm{m}], t_{i n}$ is the time of salt injection $[\mathrm{s}]$ and $t_{e}$ is the time $[\mathrm{s}$ ] when $50 \%$ of the salt has passed by the probe.

Various strategies were adopted to ensure the complete mixing of the salt in the streams: (i) food coloring was injected into the water and its dilution observed; (ii) in cascade channels the salt injection point and the probe location were at sites where the water flows in a small cross-section and; (iii) in a step-pool

\begin{tabular}{|c|c|c|c|c|}
\hline Date & Cross-section & $\begin{array}{c}\text { Number of } \\
\text { measurements }\end{array}$ & $\begin{array}{c}\text { Number of people } \\
\text { working }\end{array}$ & Time spent $[\mathrm{h}]$ \\
\hline $14 / 03 / 2017$ & $1,2,3,4,5,6,7,8,9$ and 10 & 11 & 3 & 8 \\
\hline $01 / 04 / 2017$ & $1,2,3,4,6,7,8$ and 9 & 8 & 2 & 7 \\
\hline $10 / 04 / 2017$ & 4 & 2 & 3 & 4 \\
\hline $22 / 04 / 2017$ & $1,4,5,7,8$ and 9 & 6 & 4 & 6 \\
\hline $19 / 07 / 2017$ & 23 and 24 & 2 & 4 & 8 \\
\hline $13 / 12 / 2017$ & $12,19,25,26,27,28$ and 31 & 7 & 4 & 8 \\
\hline $18 / 12 / 2017$ & 4 and 10 & 2 & 2 & 6 \\
\hline $05 / 02 / 2018$ & $10,16,18$ and 21 & 4 & 2 & 8 \\
\hline $17 / 02 / 2018$ & 29 and 30 & 2 & 2 & 4 \\
\hline $20 / 02 / 2018$ & $17,18,19,20$ and 21 & 5 & 2 & 8 \\
\hline $06 / 06 / 2018$ & $8,10,11,13,14,15$ and 21 & 8 & 4 & 5 \\
\hline $26 / 06 / 2018$ & $8,10,12,13,14$ and 15 & 6 & 4 & 5 \\
\hline $05 / 07 / 2018$ & 10 & 2 & 2 & 3 \\
\hline $14 / 08 / 2018$ & 10 & 2 & 3 & 3 \\
\hline $04 / 09 / 2018$ & 10 & 1 & 4 & 2 \\
\hline $12 / 09 / 2018$ & 10 & 3 & 3 & 5 \\
\hline $04 / 10 / 2018$ & 10 & 1 & 1 & 2 \\
\hline $18 / 06 / 2020$ & 10,12 and 13 & 6 & 3 & 6 \\
\hline
\end{tabular}
channel the salt was injected after the pool.

Table 1. Description of the monitoring campaign. 
(a)

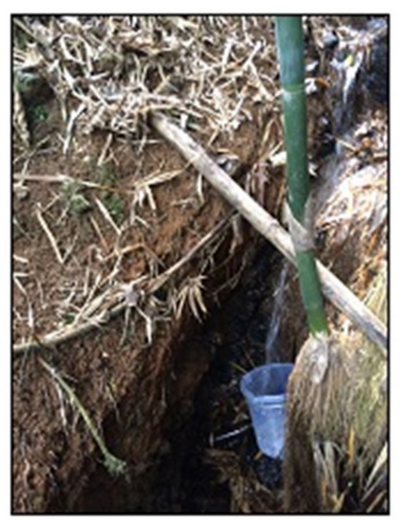

(b)

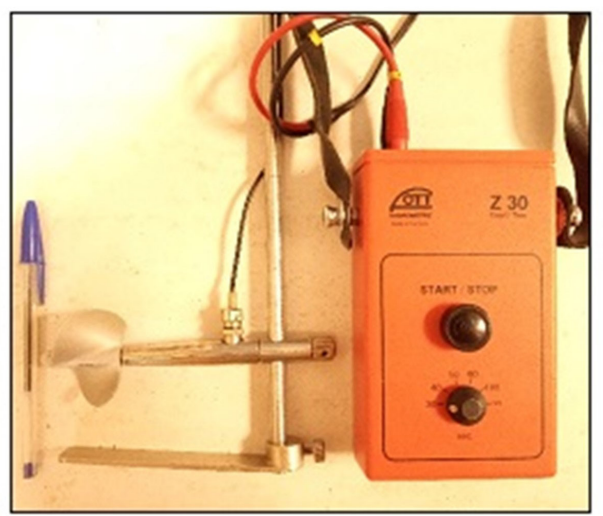

(c)

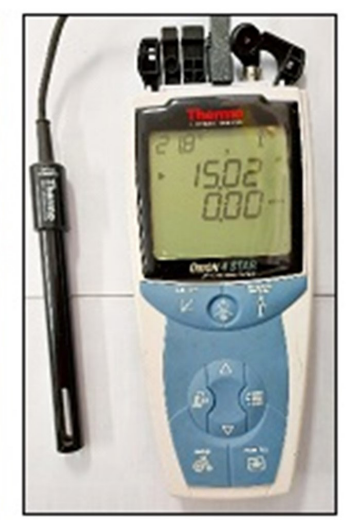

Figure 2. Streamflow measurement equipment: (a) Container of 7 L; (b) Mechanical current meter (OTT C2, OTT HydroMet, Munich, Germany); (c) Conductivity probe (Orion 4 Star, Thermo Scientific, Beverly, Massachusetts, USA).

\section{Precision and accuracy of streamflow measurements}

Precision and accuracy analysis of the dilution method was performed for streamflow measurements of each crosssection (Figure 3). Precision refers to the variability of the values found for repeated measurements (yellow box in Figure 3). The precision can be estimated when there are multiple streamflow measurements (e.g. Day, 1976).

Accuracy is the deviation of a measurement from a reference one. Most of the literature uses the streamflow measured with another method as the reference (or real) value. However, in headwater cross-sections it may not be possible to measure streamflow by more than one method. Therefore, we analyzed the accuracy of the data set in two different ways (grey boxes in Figure 3): (i) in the case that streamflow was measured with more than one method in the same cross-section, the differences between the streamflow measured with salt dilution and the other method were calculated (e.g. Benischke \& Harum, 1990; Bjerve \& Grøterud, 1980; Davids et al., 2019; Gees, 1990; Kite, 1989); (ii) in cross-section 10 we calculated it as the difference between the streamflow measured with the dilution method and the best fit of the rating curve derived using current meter measurements (e.g. Clow \& Fleming, 2008; Hudson \& Fraser, 2002).

In addition, we looked at the relationships between streamflow and drainage area, and between specific streamflow and drainage area on various days of measurement and for all our data combined. Lastly, we illustrated the relationship between streamflow and flow velocity we found using the dilution method and the current meter, respectively, and compared our results to data reported in the literature.

The precision is assessed through the percent error about the mean of duplicates and triplicates (Day, 1976). The greater the precision, the lower the error:

error $_{P}=\frac{Q_{j}-\overline{Q_{m}}}{\overline{Q_{m}}} \cdot 100$

where $Q_{j}$ is streamflow measurement $j\left[\mathrm{~L} \mathrm{~s}^{-1}\right], \overline{Q_{m}}$ is the mean value of all the measurements $\left[\mathrm{L} \mathrm{s}^{-1}\right]$.
The accuracy is assessed through the absolute percent error compared to the reference streamflow. The greater the accuracy, the lower the error. In this paper the reference streamflow is either the streamflow measured with the current meter $\left(Q_{C M}\right.$, Equation 6) or the streamflow estimated from the rating curve $\left(Q_{R C}\right.$, Equation 7):

error $_{C M}=\left|\frac{Q_{D}-Q_{C M}}{Q_{C M}}\right| \cdot 100$

$\operatorname{error}_{R C}=\left|\frac{Q_{D}-Q_{R C}}{Q_{R C}}\right| \cdot 100$

where $Q_{D}$ is the streamflow measured using the dilution method $\left[\mathrm{L} \mathrm{s}^{-1}\right]$.

The rating curve was derived in cross-section 10 where the water level gauge is located (Ribeirão Grande Watershed, crosssection 10 - Figure 1d). The rating curve was obtained from the best fit of a power-law relationship between streamflow measurements with the current meter and the corresponding water levels:

$Q_{R C}=\alpha H^{\beta}$

where $Q_{R C}$ is streamflow estimated by the rating curve, $H$ is water level $[\mathrm{cm}], \dot{a}$, and $\beta$ are regression constants.

Streamflow, flow velocity, and drainage area scaling relationships were assessed. Relating (i.e. scaling) streamflow to the catchment area, which is called "drainage area ratio method", is commonly used to estimate the streamflow in ungauged watersheds (Archfield \& Vogel, 2010). Nearby watersheds in the same landscape are often assumed to have similar specific streamflows:

$q=\frac{Q}{A}$

where $q$ is specific streamflow $\left[\mathrm{L} \mathrm{s}^{-1} \mathrm{~km}^{-2}\right], Q$ is streamflow and $A$ is catchment area $\left[\mathrm{km}^{2}\right]$. Equation 9 implies that the relationship between streamflow and area is linear. This seems to be the case above an area of around 1 to $2 \mathrm{~km}^{2}$ (e.g., Archfield \& Vogel, 2010; Egusa et al., 2016; Karlsen et al., 2016; Lyon et al., 2012; Woods et al., 1995). In order to verify the variation in the specific 


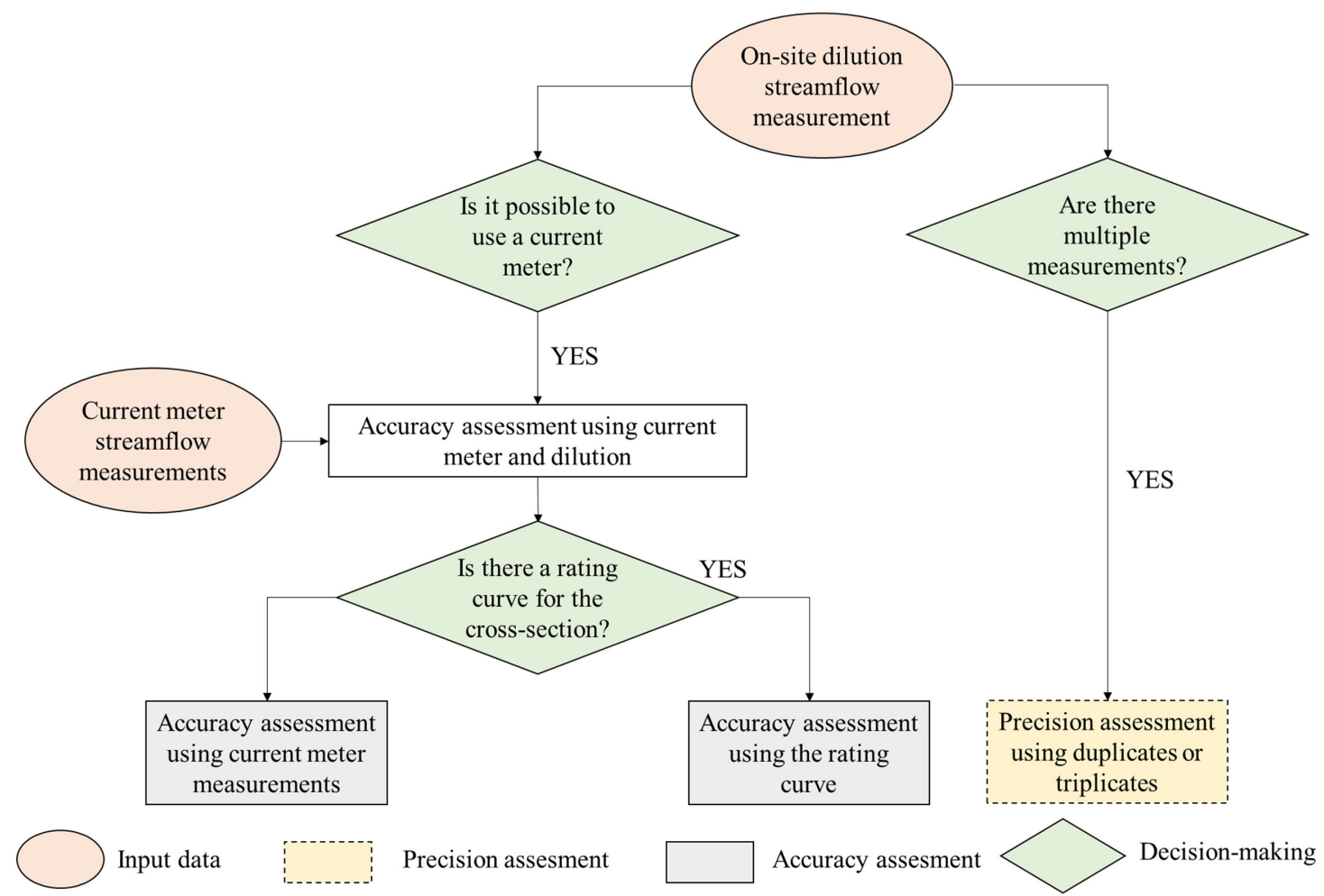

Figure 3. Flowchart showing systematically how we calculated the measurement error.

streamflow of different monitoring campaigns, we normalized the specific streamflow of each cross-section $(q n)$ by dividing the specific streamflow of each cross-section by the specific streamflow of the day $\left(q_{d}\right)$ :

$q n_{i}=\frac{q_{i}}{q_{d}}$

where $q n$ is the normalized specific streamflow at cross-section $i$ $\left[\mathrm{L} \mathrm{s}^{-1} \mathrm{~km}^{-2} / \mathrm{L} \mathrm{s}^{-1} \mathrm{~km}^{-2}\right], q$ is the specific streamflow at cross-section $i$ $\left[\mathrm{L} \mathrm{s}^{-1} \mathrm{~km}^{-2}\right]$ and $q_{d}$ is the specific streamflow on the day $\left[\mathrm{L} \mathrm{s}^{-1} \mathrm{~km}^{-2}\right]$. The specific streamflow for each day was obtained by Equation 9 .

According to Leopold \& Maddock Junior (1953), the relationship between streamflow and velocity can be described with a power-law (e.g. Bergstrom et al., 2016; Edwardson et al., 2003; Leopold, 1953; Wondzell et al., 2007):

$v=a Q^{b}$

where $v$ is the velocity $\left[\mathrm{m} \mathrm{h}^{-1}\right], a$ and $b$ are regression constants.

\section{RESULTS}

We made a total of 78 streamflow measurements, 12 measurements using the volumetric method $\left(Q_{V}\right)$ (Table 2), 57 measurements using the dilution method $\left(Q_{D}\right)$ (Table 3 ), and 9 measurements using the current meter $\left(Q_{C N}\right)$ (Table 4$)$. We observed that the volumetric method works well for small colluvial channels (Table 2), while the dilution method is ideal for cascades (Table 3), and a step-pool channel supports the dilution and current method in different cross-sections (Table 3 and Table 4).
With the volumetric method we measured streamflows between 0.01 and $0.29 \mathrm{~L} \mathrm{~s}^{-1}$ in channels with drainage areas ranging from 0.02 to $0.05 \mathrm{~km}^{2}$ (Table 2). With the dilution method we measured streamflows between 0.12 and $337.45 \mathrm{~L} \mathrm{~s}^{-1}$ in channels with drainage areas ranging from 0.02 to $5.33 \mathrm{~km}^{2}$ (Table 3). Lastly, with the current meter we measured streamflows between 6.0 and $410 \mathrm{~L} \mathrm{~s}^{-1}$ in channels with drainage areas ranging from 0.26 to $5.33 \mathrm{~km}^{2}$ (Table 4).

\section{Precision of streamflow measurements}

We assessed the precision using 46 measurements. The percent error about the mean of multiple measurements $\left(\right.$ error $\left._{p}\right)$ tends to decrease as $Q_{D}$ increases (Figure $4 \mathrm{a}$ and $\mathrm{b}$ ). The first and third quartile of error $_{P}$ of all data were $-5.0 \%$ and $4.7 \%$, respectively, and the standard deviation was $14.7 \%$ (Figure $4 \mathrm{~b}$ ). The largest error $_{p}$ are close to $1 \mathrm{~L} \mathrm{~s}^{-1}$.

\section{Accuracy of streamflow measurements}

Comparison between dilution $\left(\mathrm{Q}_{\mathrm{D}}\right)$ and current meter $\left(Q_{\mathrm{CM}}\right)$ data

In Table 5 the streamflows measured with the dilution method $\left(Q_{D}\right)$ and the current meter $\left(Q_{C M}\right)$ are compared for the seven occasions (cf. Table 4 ) when both methods were used concurrently. Here we take $Q_{C M}$ as the reference value. In six measurements $Q_{D}$ was lower than $Q_{C M}$. The percent error compared 
Table 2. Description of streamflow measurements with the volumetric method. Due to the resolution of the digital elevation model, it was not possible to calculate the area for cross-section 1.

\begin{tabular}{|c|c|c|c|c|c|c|c|}
\hline Cross-section & Date & $\begin{array}{c}\text { Mean } \\
\text { streamflow } \\
{\left[\mathrm{L} \mathrm{s}^{-1}\right]}\end{array}$ & Container [L] & $\begin{array}{l}\text { Number of } \\
\text { measurements }\end{array}$ & Area $\left[\mathrm{km}^{2}\right]$ & Order [-] & Channel type \\
\hline 1 & $14 / 03 / 2017$ & 0.04 & 0.25 & 7 & - & - & Colluvial \\
\hline 2 & $14 / 03 / 2017$ & 0.04 & 0.25 & 5 & 0.033 & $1^{\circ}$ & Cascade \\
\hline 3 & $14 / 03 / 2017$ & 0.35 & 7.00 & 3 & 0.078 & $1^{\circ}$ & Colluvial \\
\hline 5 & $14 / 03 / 2017$ & 0.08 & 0.25 & 6 & 0.018 & $1^{\circ}$ & Colluvial \\
\hline 7 & $14 / 03 / 2017$ & 0.09 & 0.25 & 6 & 0.016 & $1^{\circ}$ & Colluvial \\
\hline 9 & $14 / 03 / 2017$ & 0.24 & 7.00 & 5 & 0.047 & $1^{\circ}$ & Cascade \\
\hline 1 & $01 / 04 / 2017$ & 0.07 & 7.00 & 3 & - & - & Colluvial \\
\hline 2 & $02 / 04 / 2017$ & 0.02 & 0.25 & 7 & 0.033 & $1^{\circ}$ & Cascade \\
\hline 1 & $22 / 04 / 2017$ & 0.01 & 0.25 & 6 & - & - & Colluvial \\
\hline 5 & $22 / 04 / 2017$ & 0.28 & 7.00 & 4 & 0.018 & $1^{\circ}$ & Colluvial \\
\hline 7 & $22 / 04 / 2017$ & 0.06 & 0.25 & 4 & 0.015 & $1^{\circ}$ & Colluvial \\
\hline 31 & $13 / 12 / 2017$ & 0.29 & 7.00 & 3 & 0.047 & $1^{\circ}$ & Colluvial \\
\hline
\end{tabular}

Table 3. Description of streamflow measurements with the dilution method. NC is the number of campaigns that streamflow was measured in a cross-section. Due to the resolution of the digital elevation model, it was not possible to calculate the area for crosssection 27.

\begin{tabular}{|c|c|c|c|c|c|c|c|c|c|}
\hline $\begin{array}{l}\text { Cross- } \\
\text { Section }\end{array}$ & NC & $\begin{array}{c}\text { Mean } \\
\text { streamflow } \\
{\left[\mathrm{L} \mathrm{s}^{-1}\right]}\end{array}$ & $\begin{array}{l}\text { Velocity } \\
{\left[\mathrm{m} \mathrm{s}^{-1}\right]}\end{array}$ & Width [m] & $\begin{array}{c}\text { Mixing } \\
\text { length }[\mathrm{m}]\end{array}$ & $\begin{array}{c}\text { Amount of } \\
\text { salt added [g } \\
\left.\mathrm{L}^{-1} \mathrm{~s}\right]\end{array}$ & $\begin{array}{c}\text { Area } \\
{\left[\mathrm{km}^{2}\right]}\end{array}$ & Order [-] & $\begin{array}{c}\text { Channel } \\
\text { type }\end{array}$ \\
\hline 3 & 1 & 0.49 & - & 0.30 & - & 16.2 & 0.078 & $1^{\circ}$ & Colluvial \\
\hline 4 & 5 & $0.84-27.05$ & $0.02-0.10$ & - & $6.3-9.7$ & $1.9-15.7$ & 0.255 & $1^{\circ}$ & Cascade \\
\hline 6 & 2 & $0.57-0.61$ & - & - & - & $12.9-14.4$ & 0.121 & $1^{\circ}$ & Cascade \\
\hline 7 & 1 & 0.12 & - & 0.20 & - & 4.1 & 0.015 & $1^{\circ}$ & Colluvial \\
\hline 8 & 5 & $7.33-9.68$ & $0.07-0.12$ & - & 10.1 & 3.1 & 1.136 & $3^{\circ}$ & Cascade \\
\hline 9 & 2 & $0.24-0.60$ & 0.01 & - & 3.6 & 10.0 & 0.047 & $1^{\circ}$ & Cascade \\
\hline 10 & 11 & $9.09-337.45$ & $0.13-1.33$ & 3.90 & $6.6-16.5$ & $0.3-3.5$ & 5.331 & $4^{\circ}$ & Step-pool \\
\hline 11 & 1 & 0.73 & 0.04 & - & 3.2 & 7.5 & 0.133 & $1^{\circ}$ & Cascade \\
\hline 12 & 4 & $6.00-27.00$ & $0.08-0.21$ & 3.00 & 13.7 & 2.4-5.4 & 2.646 & $3^{\circ}$ & Cascade \\
\hline 13 & 3 & $5.90-23.75$ & $0.13-0.28$ & 0.60 & 8.2 & $2.1-2.6$ & 2.216 & $3^{\circ}$ & Undefined \\
\hline 14 & 2 & $2.2-3.2$ & $0.05-0.06$ & - & 3.2 & $6.5-7.2$ & 0.218 & $2^{\circ}$ & Cascade \\
\hline 15 & 2 & $0.6-1.1$ & $0.01-0.06$ & - & 6.5 & $20.1-24.4$ & 0.293 & $1^{\circ}$ & Cascade \\
\hline 16 & 1 & 4.74 & 0.05 & - & 7.2 & 6.3 & 0.179 & $1^{\circ}$ & Cascade \\
\hline 17 & 1 & 0.40 & 0.03 & - & 5.8 & 26.6 & 0.030 & $1^{\circ}$ & Cascade \\
\hline 18 & 2 & $1.01-1.08$ & 0.04-0.09 & - & 5.4 & $16.2-5.8$ & 0.053 & $1^{\circ}$ & Cascade \\
\hline 19 & 1 & 0.98 & - & - & - & 26.2 & 0.053 & $1^{\circ}$ & Cascade \\
\hline 20 & 1 & 1.06 & 0.06 & - & 3.4 & 20.7 & 0.052 & $1^{\circ}$ & Cascade \\
\hline 21 & 3 & $0.23-1.07$ & $0.02-0.04$ & - & 3.4 & 26.0 & 0.051 & $1^{\circ}$ & Cascade \\
\hline 22 & 1 & 0.88 & 0.02 & - & 6.3 & 9.7 & 0.049 & $1^{\circ}$ & Cascade \\
\hline 23 & 1 & 20.15 & - & - & - & 3.3 & 1.570 & $3^{\circ}$ & Step-pool \\
\hline 24 & 1 & 9.98 & - & - & - & 4.4 & 0.519 & $2^{\circ}$ & Cascade \\
\hline 25 & 1 & 6.63 & 0.05 & - & 7.5 & 9.8 & 0.130 & $2^{\circ}$ & Cascade \\
\hline 26 & 1 & 7.76 & 0.08 & - & 12.75 & 7.7 & 0.142 & $2^{\circ}$ & Cascade \\
\hline 27 & 1 & 1.70 & 0.05 & - & 5.5 & 8.7 & - & - & Cascade \\
\hline 28 & 1 & 2.36 & 0.08 & - & - & 5.1 & 0.103 & $1^{\circ}$ & Cascade \\
\hline 29 & 1 & 3.45 & 0.02 & 0.30 & 3.4 & 5.3 & 0.075 & $1^{\circ}$ & Colluvial \\
\hline 30 & 1 & 0.95 & 0.11 & - & 3.2 & 23.5 & 0.026 & $1^{\circ}$ & Cascade \\
\hline
\end{tabular}


Table 4. Description of streamflow measurements with the current meter. $10^{*}$ is the cross-section downstream, $10^{* *}$ the cross-section immediately upstream, and $10^{* * *}$ the cross-section immediately downstream of the cross-section used to measure streamflow with the dilution method. MD is the Maximum Depth, AD is the Average Depth and DBV is the Distance Between Verticals.

\begin{tabular}{|c|c|c|c|c|c|c|c|c|c|c|}
\hline $\begin{array}{l}\text { Cross- } \\
\text { Section }\end{array}$ & Date & $\begin{array}{c}\text { Mean } \\
\text { streamflow } \\
{\left[\mathrm{L} \mathrm{s}^{-1}\right]}\end{array}$ & $\begin{array}{c}\text { Velocity } \\
{\left[\mathrm{m} \mathrm{s}^{-1}\right]}\end{array}$ & $\begin{array}{c}\text { Width } \\
\text { [m] }\end{array}$ & $\begin{array}{l}\text { MD } \\
{[\mathrm{m}]}\end{array}$ & $\begin{array}{l}\text { AD } \\
{[\mathrm{m}]}\end{array}$ & $\begin{array}{c}\text { DBV } \\
{[\mathrm{m}]}\end{array}$ & $\begin{array}{c}\text { Area } \\
{\left[\mathrm{km}^{2}\right]}\end{array}$ & $\begin{array}{c}\text { Order } \\
{[-]}\end{array}$ & $\begin{array}{c}\text { Channel } \\
\text { type }\end{array}$ \\
\hline 8 & $14 / 03 / 2017$ & 8.7 & 0.03 & 1.5 & 0.25 & 0.23 & 0.3 & 1.136 & $3^{\circ}$ & Cascade \\
\hline 4 & $10 / 04 / 2017$ & 27.2 & 0.06 & 1.8 & 0.30 & 0.32 & 0.3 & 0.255 & $1^{\circ}$ & Cascade \\
\hline $10^{*}$ & $14 / 03 / 2017$ & 53.4 & 0.06 & 6.1 & 0.25 & 0.15 & 0.5 & 5.331 & $4^{\circ}$ & Dune ripple \\
\hline $10^{* *}$ & $05 / 07 / 2018$ & 40.9 & 0.02 & 4.5 & 0.50 & 0.27 & 0.5 & 5.331 & $4^{\circ}$ & Step-pool \\
\hline $10 * *$ & $14 / 08 / 2018$ & 20.0 & 0.01 & 4.5 & 0.43 & 0.21 & 0.5 & 5.331 & $4^{\circ}$ & Step-pool \\
\hline $10^{* *}$ & $04 / 09 / 2018$ & 410.0 & 0.15 & 4.5 & 0.67 & 0.41 & 0.5 & 5.331 & $4^{\circ}$ & Step-pool \\
\hline $10^{* * *}$ & $18 / 06 / 2020$ & 6.2 & 0.01 & 3.9 & 0.38 & 0.23 & 0.3 & 5.331 & $4^{\circ}$ & Step-pool \\
\hline 12 & $18 / 06 / 2020$ & 6.0 & 0.04 & 1.2 & 0.21 & 0.12 & 0.2 & 2.216 & $3^{\circ}$ & Undefined \\
\hline 13 & $18 / 06 / 2020$ & 6.3 & 0.01 & 2.4 & 0.20 & 0.09 & 0.3 & 2.646 & $3^{\circ}$ & Step-pool \\
\hline
\end{tabular}

(a)

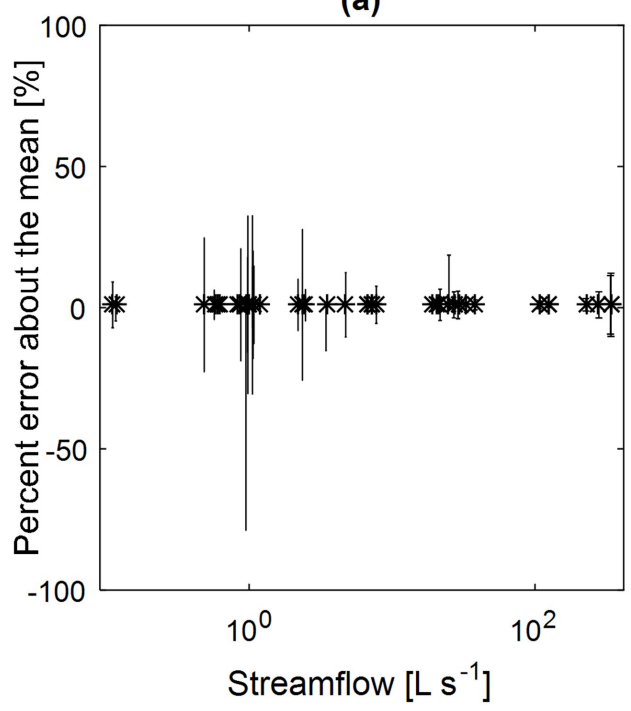

(b)

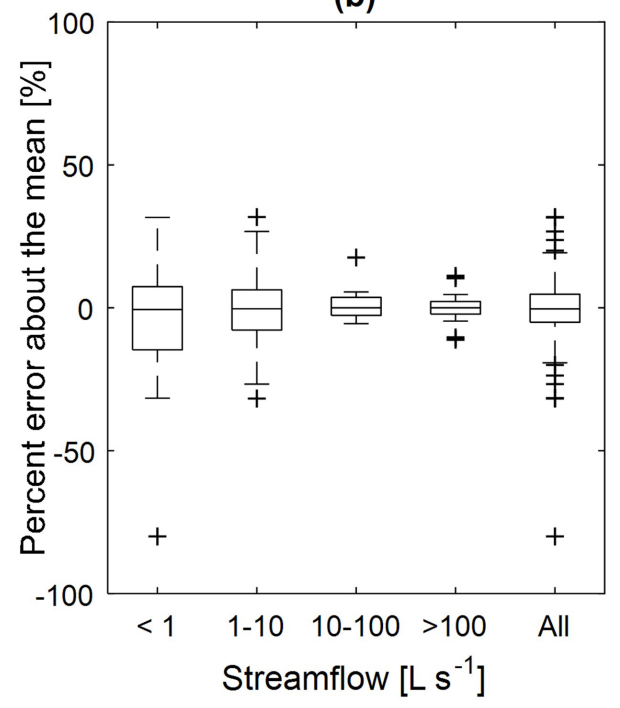

Figure 4. Precision assessment: (a) Percent error about the mean of multiple measurements, star $\left(^{*}\right)$ is the mean streamflow measurement and bars is the percent error about the mean for each cross-section; (b) Summary of the percent error about the mean of multiple measurements. The box indicates the 25th and 75th percentiles, the central mark indicates the median, and the whiskers extend to the most extreme data points not considered outliers. Outliers are plotted individually using the plus symbol (+).

Table 5. Difference in streamflow obtained with the dilution method and the current meter. error $_{C M}$ is the percent error compared to the reference streamflow which is taken here as the one obtained with the current meter.

\begin{tabular}{cccc}
\hline $\left.\begin{array}{c}\text { Streamflow - } \\
\text { Dilution [L s }\end{array}{ }^{-1}\right]$ & $\begin{array}{c}\text { Streamflow - } \\
\text { Current meter } \\
{\left[\mathbf{L ~ s}^{-1}\right]}\end{array}$ & $\begin{array}{c}\text { error } \\
{[\%]}\end{array}$ & $\begin{array}{c}\text { Cross- } \\
\text { section }\end{array}$ \\
\hline 5.90 & 6.03 & 2.28 & 13 \\
6.00 & 6.35 & 5.57 & 12 \\
7.33 & 8.70 & 15.77 & 8 \\
9.09 & 6.24 & 45.63 & 10 \\
19.13 & 19.98 & 4.25 & 10 \\
27.05 & 27.24 & 0.70 & 4 \\
38.31 & 40.90 & 6.33 & 10 \\
\hline
\end{tabular}

to $Q_{C M}$ (error $\left.r_{C M}\right)$, which is taken as the reference streamflow here, ranged from $0.70 \%$ to $45.63 \%$. The largest error ${ }_{C M}$ was for the lowest streamflow in cross-section 10 (Figure 1d). Despite the small number of samples, these data are important, given the scarcity of streamflow measurements with more than one method in cross-sections in headwater streams under baseflow conditions.

Comparison between dilution $\left(Q_{D}\right)$ and rating curve $\left(Q_{R C}\right)$ data

In Table 6 the streamflows obtained with the dilution method $\left(Q_{D}\right)$ and the rating curve $\left(Q_{R C}\right)$ are compared for the nine occasions when both methods were used concurrently. Now $Q_{R C}$ 
Table 6. Difference in streamflow measurement with the dilution method and the rating curve. error $_{\mathrm{RC}}$ is the percent error compared to the reference streamflow which is taken here as the one obtained from the rating curve.

\begin{tabular}{cccc}
\hline $\begin{array}{c}\text { Streamflow - } \\
\text { Dilution }\left[\mathbf{L ~ s}^{-1}\right]\end{array}$ & $\begin{array}{c}\text { Streamflow - } \\
\text { Rating curve }\left[\mathbf{L ~ s}^{-1}\right]\end{array}$ & $\begin{array}{c}\text { error } \\
{[\boldsymbol{R} \text { [ }]}\end{array}$ & $\begin{array}{c}\text { Cross- } \\
\text { section }\end{array}$ \\
\hline 19.14 & 21.96 & 12.86 & 10 \\
28.98 & 27.37 & 5.85 & 10 \\
33.04 & 33.47 & 1.30 & 10 \\
38.31 & 40.27 & 4.86 & 10 \\
125.55 & 121.94 & 2.96 & 10 \\
227.00 & 371.18 & 38.84 & 10 \\
280.00 & 299.85 & 6.62 & 10 \\
294.00 & 396.89 & 25.92 & 10 \\
337.45 & 237.02 & 42.37 & 10 \\
\hline
\end{tabular}

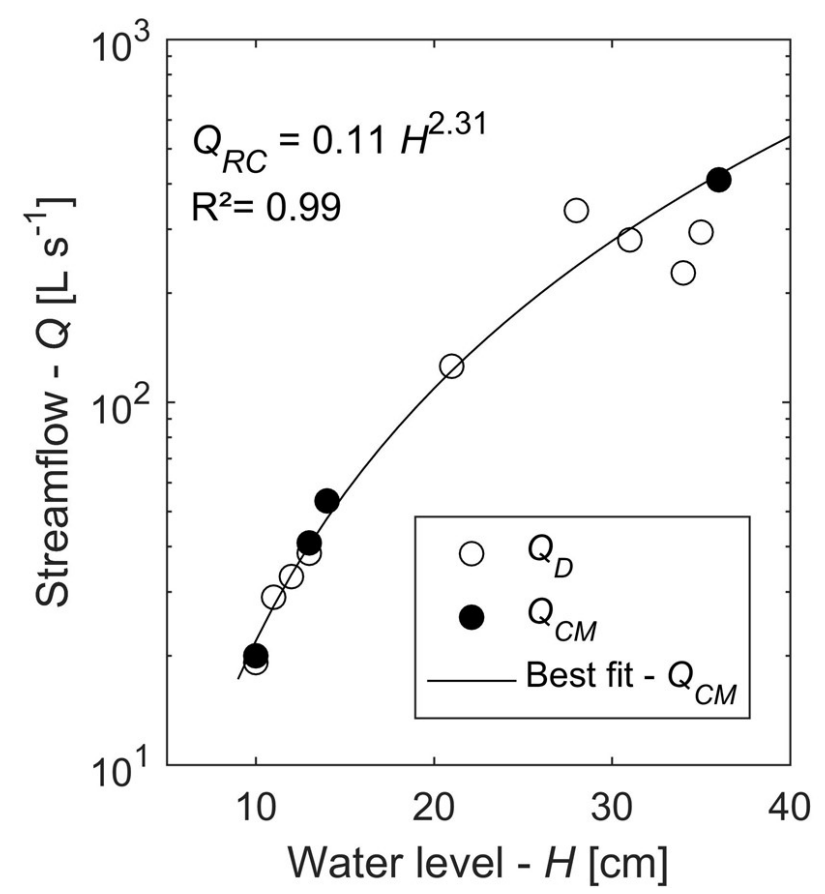

Figure 5. Rating curve derived from streamflow measurements with the current meter. $Q_{D}$ is the streamflow measured with the dilution method and $Q_{C M}$ is the streamflow measured with the current meter.

is taken as the reference value. The absolute percent error ranged from $1.30 \%$ to $42.37 \%$, the median was $6.6 \%$. The rating curve (Figure 5) was derived from measurements with the current meter between March 14, 2017 and September 12, 2018. After that date the cross-section was modified by a severe storm and we could not use the same rating curve.

\section{Streamflow and drainage area}

The relationship between streamflow and drainage area can be derived by linear regression (Figure 6). All 55 measurements are fitted quite well by the same regression line $\left(R^{2}=0.68\right) . R^{2}$ was $\geq 0.79$ on all individual monitoring days. The measurements made to derive the rating curve were not considered.

\section{Specific streamflow and drainage area}

The standard deviation of the normalized specific streamflow (qn) (Equation 10) was $1.14 \mathrm{~L} \mathrm{~s}^{-1} \mathrm{~km}^{-2} / \mathrm{L} \mathrm{s}^{-1} \mathrm{~km}^{-2}$ (40 samples) in cross-sections with a drainage area $<1 \mathrm{~km}^{2}$ (Figure 7). For crosssections with a drainage area $>1 \mathrm{~km}^{2}$ (15 samples), the standard deviation dropped to $0.16 \mathrm{~L} \mathrm{~s}^{-1} \mathrm{~km}^{-2} / \mathrm{L} \mathrm{s}^{-1} \mathrm{~km}^{-2}$. The standard deviation of all data sets combined was $1.00 \mathrm{~L} \mathrm{~s}^{-1} \mathrm{~km}^{-2} / \mathrm{L} \mathrm{s}^{-1} \mathrm{~km}^{-2}$ (Figure 7).

Similar $q n$ values are spatially close (Figure 8 ). In most cases $q n$ values on the east coast (region R1 - Figure 8) are below the $1.00 \mathrm{~L} \mathrm{~s}^{-1} \mathrm{~km}^{-2} / \mathrm{L} \mathrm{s}^{-1} \mathrm{~km}^{-2}$ in Figure 7. The region R1 (cross-section 2, 4, 6, 7 - Figure 1d) is characterized by a low altitude and the presence of alluvial sediments near the Lake (seen in the field). The drainage area of these cross-sections is $<0.3 \mathrm{~km}^{2}$. Cross-sections 8 and 10 are in the same region (Figure $1 \mathrm{~d}$ ), but the drainage area is $>1 \mathrm{~km}^{2}$ and the $q n$ are close to the $1.00 \mathrm{~L} \mathrm{~s}^{-1} \mathrm{~km}^{-2} / \mathrm{L} \mathrm{s}^{-1} \mathrm{~km}^{-2}$.

Cross-section 10 is the outlet of the Ribeirão Grande watershed (Figure 1d). This watershed is characterized by dikes and pasture (Figure 1b, 1c). Cross-section 10 had similar streamflow to cross-section 13 (Figure 1d) on two campaign days. However, the drainage area of cross-section 13 is only half that of cross-section 10. Upstream of cross-section 10, in region R2, cross-sections 12, 13, and 14 have a qn above $1.00 \mathrm{~L} \mathrm{~s}^{-1} \mathrm{~km}^{-2} / \mathrm{L} \mathrm{s}-1 \mathrm{~km}^{-2}$ (Figure 8).

The data are shown in green in Figure 7 represent crosssections on the same stream in region R3 (Figure 8) and have $q n$ values close to $1.00 \mathrm{~L} \mathrm{~s}^{-1} \mathrm{~km}^{-2} / \mathrm{L} \mathrm{s}^{-1} \mathrm{~km}^{-2}$. The data shown in yellow in Figure 7 are from areas under Atlantic forest and at higher altitudes (region R4 in Figure 8). Here $q n$ is above or near $1.00 \mathrm{~L} \mathrm{~s}^{-1} \mathrm{~km}^{-2} / \mathrm{L} \mathrm{s}^{-1} \mathrm{~km}^{-2}$.

\section{Flow velocity and streamflow}

We measured the flow velocity 52 times, 43 times with the dilution method $\left(v_{D}\right)$, and 9 times with the current meter $\left(v_{C M}\right)$. There is a power-law relationship (see Equation 11) between $v_{\mathrm{D}}$ and $Q_{D}$ (Figure 9 and Table 7) when the entire data set is considered. The regression lines for the current meter data $\left(v_{C M}\right)$ and the data obtained with the dilution method $\left(v_{D}\right)$ have a similar slope (b), but the intercept for the $v_{C M}$ data $(a)$ is about $100 \mathrm{~m} \mathrm{~h}^{-1}$ lower (Table 7) because the $v_{C M}$ are lower than the $v_{D}$ so that the regression line runs lower (Figure 9). When only cross-sections of first and second order streams are considered, it is not possible to verify a power-law relationship (Table 7).

Our dilution method data lie above or among the data from other studies, while our current meter data lie below them (Figure 10). We can see in Table 7 that the values of the regression parameters are inside the range found in other studies. All values for $a$ and $b$ in Table 7 have a p-value $<0.05$. 


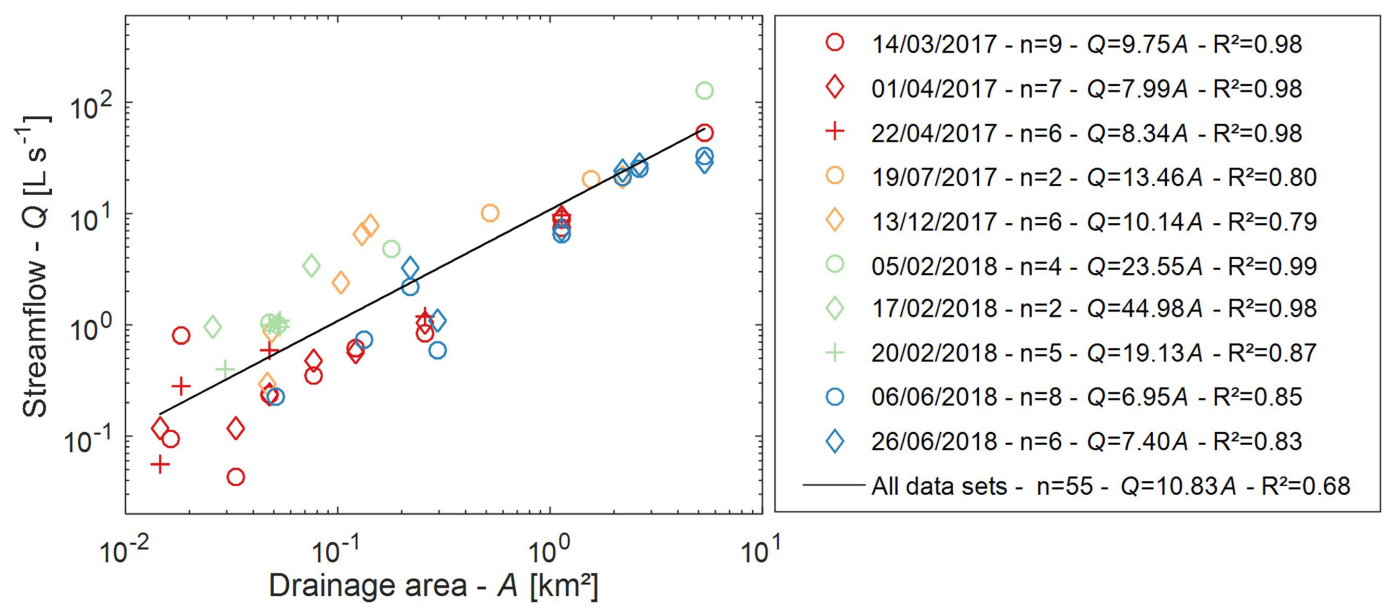

Figure 6. Relationship between streamflow and drainage area. Data are shown on a log-log scale to facilitate visualization.

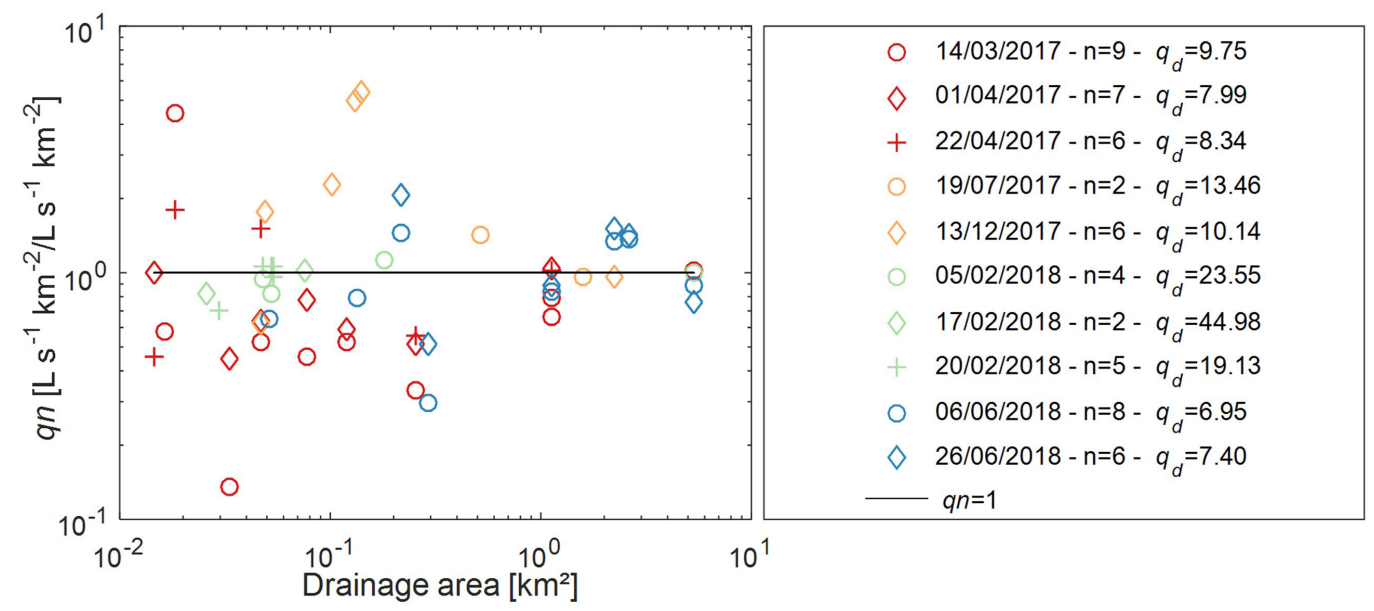

Figure 7. Relationship between normalized specific streamflow $(q n)$ and drainage area.

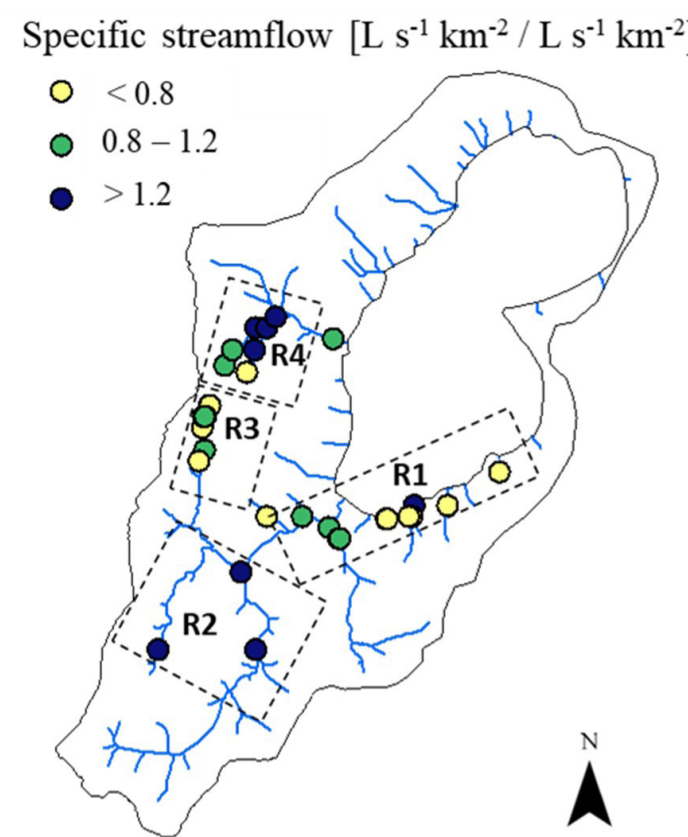

Figure 8. Spatial distribution of the specific streamflow. Each circle represents the average of the normalized specific streamflow measured in the cross-section. R1, R2, R3, and R4 represent different regions of the Peri Lake Watershed. 


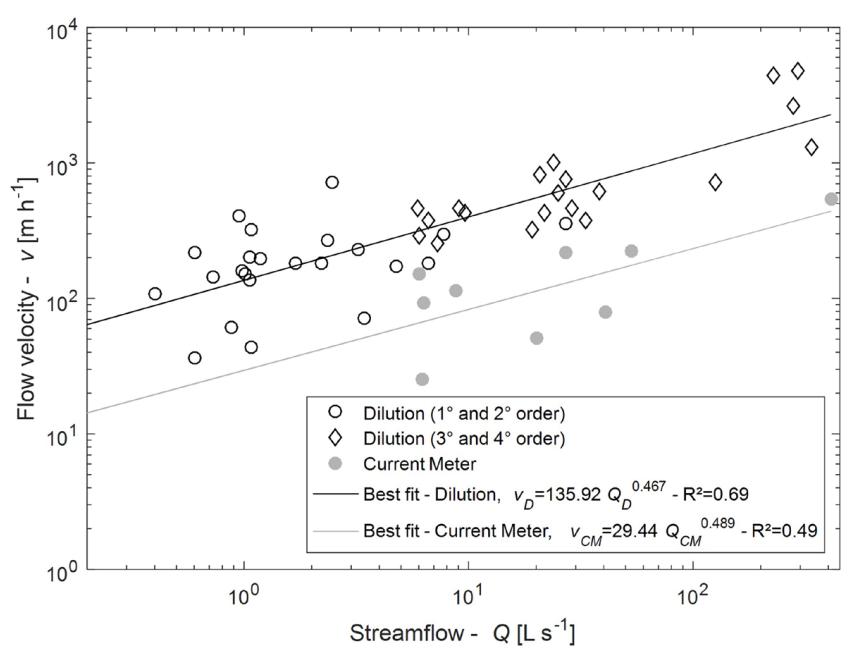

Figure 9. Relationship between streamflow and flow velocity.
Table 7. Values of the parameters $a$ and $b$ in power-law regressions (Equation 11) between streamflow $\left(\mathrm{L} \mathrm{s}^{-1}\right)$ and flow velocity $\left(\mathrm{m} \mathrm{h}^{-1}\right)$. $\mathrm{n}$ is the number of data points in the regression, $\mathrm{R}^{2}$ reflects the goodness of fit, PLW stands for Peri Lake Watershed.

\begin{tabular}{lrccc}
\hline \multicolumn{1}{c}{ Study } & \multicolumn{1}{c}{$\boldsymbol{a}$} & $\boldsymbol{b}$ & $\mathbf{n}$ & $\mathbf{R}^{2}$ \\
\hline D’Angelo et al. (1993) $^{2}$ & 195.0 & 0.21 & 22 & 0.6 \\
Morrice et al. (1997) & 53.8 & 0.52 & 17 & 0.9 \\
Edwardson et al. (2003) & 101.0 & 0.29 & 31 & 0.4 \\
Wondzell et al. (2007) & 4.6 & 1.78 & 5 & 0.9 \\
Bergstrom et al. (2016) & 336.0 & 0.18 & 16 & 0.6 \\
PLW (Current meter) & 29.4 & 0.47 & 9 & 0.5 \\
PLW (Dilution $1^{\circ}$ and $2^{\circ}$ order) & 145.5 & 0.28 & 23 & 0.1 \\
PLW (Dilution $3^{\circ}$ and $4^{\circ}$ order) & 115.4 & 0.53 & 20 & 0.7 \\
PLW (Dilution) & 135.9 & 0.49 & 43 & 0.7 \\
\hline
\end{tabular}

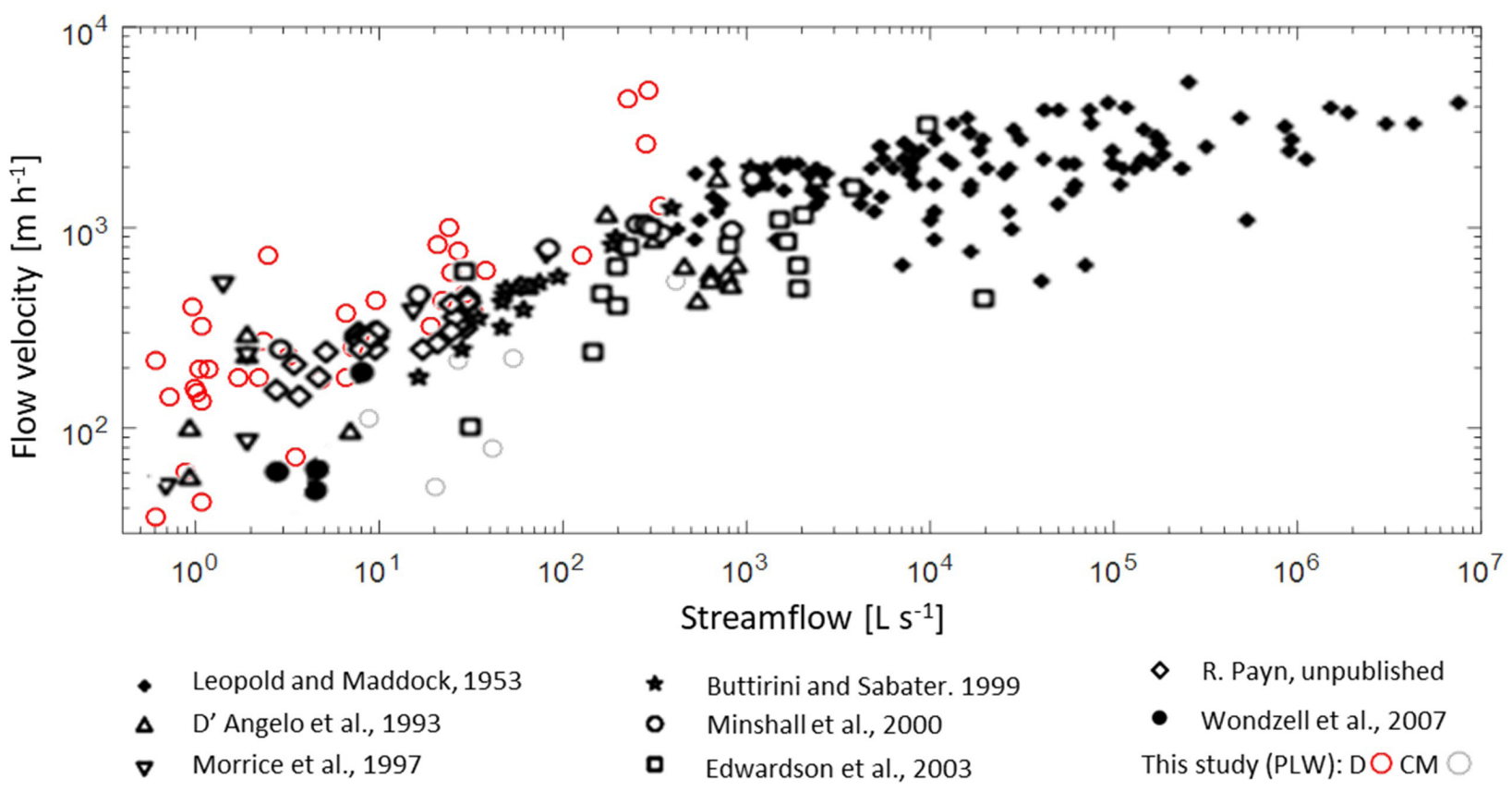

Figure 10. Relationship between flow velocity and streamflow for a wide range of stream sizes and channel morphologies from several rivers. Adapted from Wondzell et al. (2007). PLW stands from Peri Lake Watershed, D for dilution method and CM for current meter.

\section{DISCUSSION}

\section{Choice of the streamflow measurement method}

Here we discuss some particularities observed in the field for each method. All channels where the volumetric method was used are first order and mostly colluvial channels. The main problem related to the use of this method in natural channels is that it is only feasible for small volumes and that all the water of the cross-sections must flow to the same point.

Concerning the slug dilution method, Day (1977) recommends a distance of 25 times the width of the channel so that there is a complete mixing of the tracer in the water. However, the method assumes that the mixing length should be straight with no pools. We noticed that there are pools between intervals smaller than 25 times the width of the channel in cascade and step-pool channels, which led us to adopt shorter distances. According to Montgomery \& Buffington (1997), step-pool has a pool every 4 times the width of the channel, and cascade has a pool less than 1 time the width of the channel. However, in our study we noticed that this relationship varies with the flow. We observed that the lower the streamflow, the greater the number of pools in the channels. For example, in cross-section 4 (Figure 1d) the distance between two pools is 6.3 meters with a streamflow of $1.19 \mathrm{~L} \mathrm{~s}^{-1}$. When the streamflow was $27.05 \mathrm{~L} \mathrm{~s}^{-1}$, the distance between pools increased to 9.7 meters.

On June 18, 2020, streamflow was measured in the driest conditions in the watershed encountered during this work. In this campaign the minimum velocity required for the propeller of the current meter to rotate was reached in just 2 of the 14 verticals. Therefore, $Q_{C M}$ was probably below the actual streamflow. 
The dilution method was the most appropriate to use in headwater stream because: (i) the irregular channel geometry and turbulent flow conditions ensure the complete mixing of the tracer in the water, while they do not allow the use of the volumetric or current meter method; (ii) streamflow measurements using the dilution method took us on average twenty minutes, while the current meter took us one hour per measurement, and (iii) the equipment used in the dilution method is easier to transport and has a lower cost when compared to the current meter. Also, Davids et al. (2019) concluded that the dilution method yields the most accurate measurements among streamflow measurement methods with low cost and low technical complexity.

\section{Precision and accuracy errors}

In our data set streamflow measurements with the dilution method at lower water levels had less spread dispersion around the rating curve than measurements at higher levels (Figure 5). According to McMillan et al. (2012) the confidence bounds of the rating curve have typical values of $50-100 \%$ for low flows, $10-20 \%$ for medium or high (in-bank) flows, and a single estimate of $40 \%$ for out of bank flows. In our data set there is less uncertainty in the rating curve at lower flow rates, different from what is indicated in the review article of McMillan et al. (2012). Besides, using the dilution method makes it is possible to measure streamflow even at low water levels, where sometimes it is not possible to use a current meter. Because the dilution method showed good results for low streamflow measurements, the use of the dilution method could improve the derivation of the rating curve at low flows.

Day (1976) found a percent error about the mean of duplicates and triplicates $\left(\right.$ error $\left._{\mathrm{p}}\right)$ in the dilution method of up to $10-20 \%$, although such percentages were infrequent. The most probable error $_{p}$ were, however, considerably less, ranging from about 4 to $7 \%$. In Day (1976) streamflow between 130 and $6110 \mathrm{~L} \mathrm{~s}^{-1}$ was measured, while our streamflow varied between 0.11 and $340 \mathrm{~L} \mathrm{~s}^{-1}$. Even with the difference in scale between streamflow, the error $_{p}$ were in the same order of magnitude.
With the current meter, error may range from 0.3 to 2.8\% (Smoot \& Carter, 1968), or from 1.4 to 5.1\% (Schneider \& Smoot, 1976). In the studies of Smoot \& Carter (1968) and Schneider \& Smoot (1976) the error $r_{P}$ is inversely proportional to $Q_{C M}$, as in our results.

Hudson \& Fraser (2002) estimated the error ${ }_{R C}$ of streamflow measurements with the dilution method and found it to be $5.5 \%$ on average in a stream with a drainage area of $8.6 \mathrm{~km}^{2}$. The error of our values was on average $9.0 \%$ in a stream with a drainage area of $5.3 \mathrm{~km}^{2}$. Hence, the values from our study are similar to those of Hudson \& Fraser (2002).

In general, the values found in the literature indicate that the error $_{\text {RC }}$ (e.g. Clow \& Fleming, 2008; Hudson \& Fraser, 2002) is smaller than the error when comparing two measurement methods (e.g. Benischke \& Harum, 1990; Bjerve \& Grøterud, 1980; Davids et al., 2019; Gees, 1990; Kite, 1989). The opposite occurred with the data from our study. When we consider error $r_{C M}$ and error ${ }_{R C}$ together the errors are between 3.3 and $19.4 \%$ for the first and third percentile.

Other work in the literature found similar measurement errors (Figure 11), even in rivers with higher streamflow. Figure 11 shows the relative errors as (i) the RMSE of the rating curve (Clow \& Fleming, 2008; Hudson \& Fraser, 2002); (ii) the average of the percent error compared to a reference streamflow (Benischke \& Harum, 1990; Bjerve \& Grøterud, 1980; Davids et al., 2019) and; (iii) the most probable percent error compared to reference streamflow (PLW - this study; Gees, 1990; Kite, 1989).

\section{Relationship between streamflow and drainage area}

Although there is a high variation in normalized specific streamflow $(q n)$, this variation may not be related to the streamflow measurement errors, but to the characteristics of the watershed. Watersheds with smaller areas have a greater variation in $q n$ than larger watersheds (Figure 7). Our data indicates that the variation of $q n$ tends to decrease once the drainage area exceeds $1 \mathrm{~km}^{2}$. Woods et al. (1995) used a current meter to measure streamflow and

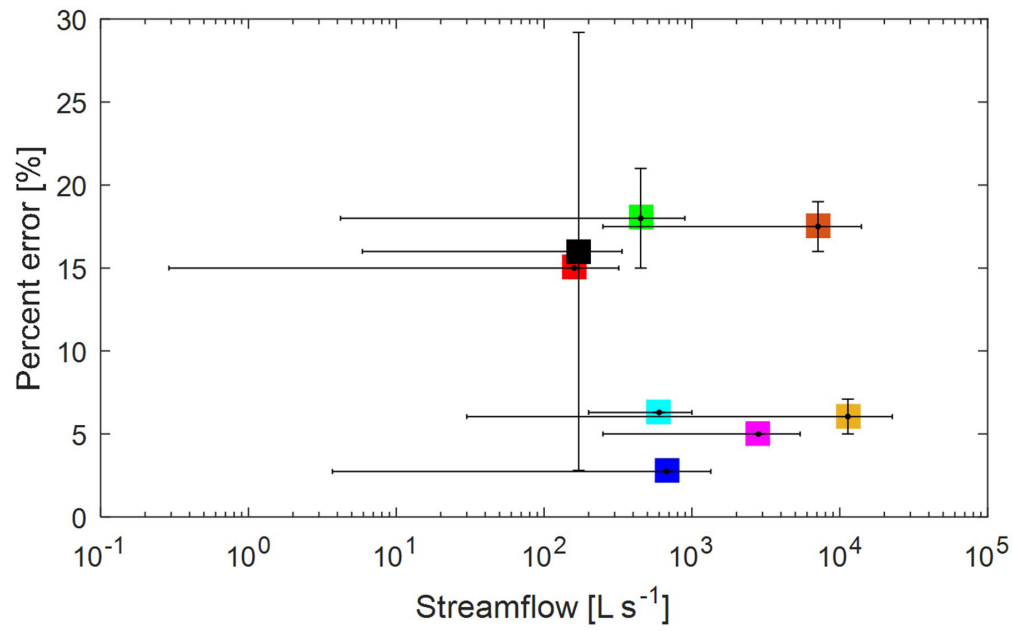

\begin{tabular}{|l}
\hline$\square$ \\
Benischke and Harum (1990) \\
Bjerve and Grosterrud (1980) \\
Clow and Fleming (2008) \\
Davids et al. (2019) \\
Gees (1990) \\
Hudson and Fraser (2002) \\
Kite (1989) \\
PLW - This study
\end{tabular}

Figure 11. Variation of absolute percent error compared to reference streamflow from the literature. The squares indicate the average of maximum and minimum percentage error and maximum and minimum streamflow, the whiskers extend to the most extreme data points of streamflow and percent error. 
found that the spatial variability of the baseflow declined markedly when the drainage area reached 0.5 to $2 \mathrm{~km}^{2}$. This threshold is called "representative elementary area" (REA). Asano \& Uchida (2010) investigated the REA via the concentration of silica and found a large spatial variation of this concentration until an area of $>0.1$ to $1 \mathrm{~km}^{2}$ was considered. Egusa et al. (2016) found that the REA is around $1 \mathrm{~km}^{2}$. The variation in $q_{n}$ may not be related to streamflow measurement errors, because similar REA were determined using different measurement methods.

Some studies show that $q n$ is related to physical characteristics of the watershed, such as altitude (e.g. Egusa et al., 2016; Lyon et al., 2012), vegetation cover (Karlsen et al., 2016; Lyon et al., 2012; Wohl et al., 2012) and exchanges between rivers and the hyporheic zone (e.g. Godsey \& Kirchner, 2014). The qn in our study is weakly related to the slope $\left(\mathrm{R}^{2}=0.24\right.$, data not shown) and the altitude $\left(\mathrm{R}^{2}=0.13\right.$, data not shown). Cross-sections near the lake have a lower $q n$, which might be due to water exchanges between the river and the soil, because the soil is formed by alluvial sediment and has a high infiltration capacity. The Peri Lake geology contains dikes, which may explain the exchange of groundwater between sub-basins. In summary, what we observed is that the variation of $q n$ may be associated with: (i) altitude and slope; (ii) water exchanges between the river and the soil; (iii) land cover and; (iv) geological formation.

\section{Relationship between streamflow and flow velocity}

The velocity is not uniform across stream networks, because of differences in fluvial geometry (Leopold \& Maddock Junior, 1953). The headwater drainage network in our study area is formed mainly by cascade channels where there is a great variation in velocity between cross-sections which change between fast flow and pools. The velocity measured using the dilution method represents an average velocity in the mixing length, while the velocity measured with the current meter represents the velocity of a single crosssection. The choice of the streamflow monitoring cross-section might overestimate the average velocity of the stream when the dilution method is used, since the cross-section is chosen so that there is enough turbulence to ensure complete mixing. On the other hand, the cross-sections chosen to measure streamflow with the current meter must have a sufficient water level to support the operation of the device and this occurs only in cross-sections where the flow is slower. Using the current meter and dilution simultaneously to calculate the velocity is the ideal approach to characterize the flow velocity in the drainage network.

It was not possible to verify a general relationship between velocity and streamflow in first and second order streams under baseflow conditions. One explanation could be that there are two mechanisms that control flow velocity: (i) hydrodynamic dispersion, which occurs within the individual flow channel, and (ii) geomorphological dispersion, which changes according to the geometry of the network (Rinaldo et al., 1991). Both dispersion coefficients increase with increasing stream order (White et al., 2004). If same order streams of a watershed have similar hydraulic patterns, this indicates the velocity must be similar in streams of the same order.

\section{CONCLUSION}

We found that the dilution was the best measuring method for the cascade morphology which we found in most of our headwaters. The dilution method is efficient even at low water levels, where the current meter cannot be used. The precision of the dilution measurements was around $\pm 5.0 \%$ with a standard deviation of $14.7 \%$. The error compared to a reference streamflow ranged from 0.7 to $45.6 \%$. Precision and accuracy are in the same order of magnitude found in the literature for higher streamflows.

The relationship between streamflow and the drainage area is linear. Watersheds with smaller drainage areas have a greater variation in the specific streamflow between them than larger watersheds. The baseflow of the cross-sections is related to the characteristics of the drainage area and the exchange between the stream and the soil. It was possible to verify the power-law relationship between velocity and streamflow for the data set only when fourth order streams were considered. As can be expected, the first and second order streams are more heterogeneous in geometry and flow velocity. We recommend the use of more than one measurement method in these streams.

Although the accuracy of measured streamflow for first and second order streams has been estimated, knowing the magnitude of absolute errors for these streams is still a challenge. Our results can be applied to improve the quantification of streamflow in headwaters and further constrain the uncertainty estimation in rainfall-runoff modeling. We hope that this work will encourage further research involving streamflow measurements in headwater streams under baseflow conditions.

\section{ACKNOWLEDGEMENTS}

This research was funded by $\mathrm{CNPq}$ (in Portuguese, Conselho Nacional de Desenvolvimento Científico e Tecnológico) projects MCTI/CNPQ/Universal No 14/2014 and No 28/2018. CIS and ABAP thank CAPES (in Portuguese, Coordenação de Aperfeiçoamento de Pessoal de Nível Superior) for the scholarship. PFA and JHMS thank CNPq for the scholarship. The authors acknowledge the two reviewers for the detailed comments that greatly improved the manuscript.

\section{REFERENCES}

Alexander, R. B., Smith, R. A., \& Schwarz, G. E. (2000). Effect of stream channel size on the delivery of nitrogen to the Gulf of Mexico. Nature, 403(6771), 758-761.

Archfield, S. A., \& Vogel, R. M. (2010). Map correlation method: selection of a reference streamgage to estimate daily streamflow at ungaged catchments. Water Resources Research, 46(10), 1-15.

Asano, Y., \& Uchida, T. (2010). Is representative elementary area defined by a simple mixing of variable small streams in headwater catchments? Hydrological Processes, 24(5), 666-671.

Benischke, R., \& Harum, T. (1990). Determination of discharge rates in turbulent streams by salt tracer dilution applying a microcomputer 
system. Comparison with current meter measurements. Hydrology in Mountainous Regions I, 193, 215-221.

Bergstrom, A., McGlynn, B., Mallard, J., \& Covino, T. (2016). Watershed structural influences on the distributions of stream network water and solute travel times under baseflow conditions. Hydrological Processes, 30(15), 2671-2685.

Bjerve, L., \& Grøterud, O. (1980). Discharge measurements by a new-formed relative salt-dilution method in small turbulent streams. Nordic Hydrology, 11(3-4), 121-132.

Clow, D. W., \& Fleming, A. C. (2008). Tracer gauge: an automated dye dilution gauging system for ice-affected streams. Water Resources Research, 44(12), 1-11.

Cohn, T. A., Kiang, J. E., \& Mason Junior, R. R. (2013). Estimating discharge measurement uncertainty using the interpolated variance estimator. Journal of Hydraulic Engineering, 139(5), 502-510.

D’Angelo, D. J., Webster, J. R., Gregory, S. V., \& Meyer, J. L. (1993). Transient storage in Appalachian and Cascade mountain streams as related to hydraulic characteristics. Journal of the North American Benthological Society, 12(3), 223-235.

Davids, J. C., Rutten, M. M., Pandey, A., Devkota, N., Van Oyen, W. D., Prajapati, R., \& Van de Giesen, N. (2019). Citizen science flow: an assessment of simple streamflow measurement methods. Hydrology and Earth System Sciences, 23(2), 1045-1065.

Day, T. J. (1976). On the precision of salt dilution gauging. Journal of Hydrology, 31(3-4), 293-306.

Day, T. J. (1977). Observed mixing lengths in mountain streams. Journal of Hydrology, 35(1-2), 125-136.

Dooge, J. C. I. (1973). Linear theory of bydrologic systems (Technical Bulletin, No. 1468). Washington: United States Department of Agriculture.

Doyle, M. W., Stanley, E. H., Strayer, D. L., Jacobson, R. B., \& Schmidt, J. C. (2005). Effective discharge analysis of ecological processes in streams. Water Resources Research, 41(11), 1-16.

Edwardson, K. J., Bowden, W. B., Dahm, C., \& Morrice, J. (2003). The hydraulic characteristics and geochemistry of hyporheic and parafluvial zones in Arctic tundra streams, north slope, Alaska. Advances in Water Resources, 26(9), 907-923..

Egusa, T., Kumagai, T., Oda, T., Gomi, T., \& Ohte, N. (2019). Contrasting patterns in the decrease of spatial variability with increasing catchment area between stream discharge and water chemistry. Water Resources Research, 55(8), 7419-7435.

Egusa, T., Ohte, N., Oda, T., \& Suzuki, M. (2016). Quantifying aggregation and change in runoff source in accordance with catchment area increase in a forested headwater catchment. Hydrological Processes, 30(22), 4125-4138.
Freeman, M. C., Pringle, C. M., \& Jackson, C. R. (2007). Hydrologic connectivity and the contribution of stream headwaters to ecological integrity at regional scales. Journal of the American Water Resources Association, 43(1), 5-14.

Gees, A. (1990). Flow measurement under difficult measuring conditions: field experience with the salt dilution method. Hydrology in Mountainous Regions I, 193, 255-262.

Godsey, S. E., \& Kirchner, J. W. (2014). Dynamic, discontinuous stream networks: hydrologically driven variations in active drainage density, flowing channels and stream order. Hydrological Processes, 28(23), 5791-5803.

Hudson, R., \& Fraser, J. (2002). Alternative methods of flow rating in small coastal streams. Forest Research, 2, 1-6.

Karlsen, R. H., Seibert, J., Grabs, T., Laudon, H., Blomkvist, P., \& Bishop, K. (2016). The assumption of uniform specific discharge: unsafe at any time? Hydrological Processes, 30(21), 3978-3988.

Kite, G. (1989). An extension to the salt dilution method of measuring streamflow. International Journal of Water Resources Development, 5(1), 19-24.

Kite, G. (1993). Computerized streamflow measurement using slug injection. Hydrological Processes, 7(2), 227-233.

Kondolf, G. M., \& Piégay, H. (Eds.). (2016). Tools in fluvial geomorphology. Oxford: Wiley Blackwell.

Leopold, L. B. (1953). Downstream change of velocity in rivers. American Journal of Science, 251(8), 606-624.

Leopold, L. B., \& Maddock Junior, T. J. (1953). The hydraulic geometry of stream channels and some physiographic implications. Geological Survey Professional Paper, 252, 1-57. http://dx.doi. org/10.3133/pp252.

Lyon, S. W., Nathanson, M., Spans, A., Grabs, T., Laudon, H., Temnerud, J., Bishop, K. H., \& Seibert, J. (2012). Specific discharge variability in a boreal landscape. Water Resources Research, 48(8), 1-13.

McMillan, H., Freer, J., Pappenberger, F., Krueger, T., \& Clark, M. (2010). Impacts of uncertain river flow data on rainfall-runoff model calibration and discharge predictions. Hydrological Processes, 24(10), 1270-1284.

McMillan, H., Krueger, T., \& Freer, J. (2012). Benchmarking observational uncertainties for hydrology: rainfall, river discharge and water quality. Hydrological Processes, 26(26), 4078-4111.

McMillan, H., Seibert, J., Petersen-Overleir, A., Lang, M., White, P., Snelder, T., Rutherford, K., Krueger, T., Mason, R., \& Kiang, J. (2017). How uncertainty analysis of streamflow data can reduce costs and promote robust decisions in water management applications. Water Resources Research, 53(7), 5220-5228. 
Miller, M. P., Buto, S. G., Susong, D. D., \& Rumsey, C. A. (2016). The importance of base flow in sustaining surface water flow in the Upper Colorado River Basin. Water Resources Research, 52(5), 3547-3562.

Montgomery, D. R., \& Buffington, J. M. (1997). Channel-reach morphology in mountain drainage basins. Bulletin of the Geological Society of America, 109(5), 596-611.

Montgomery, D. R., \& Dietrich, W. E. (1989). Source areas, drainage density, and channel initiation. Water Resources Research, 25(8), 1907-1918.

Morrice, J. A., Valett, H. M., Dahm, C. N., \& Campana, M. E. (1997). Alluvial characteristics, groundwater: surface water exchange and hydrological retention in headwater streams. Hydrological Processes, 11(3), 253-267.

Peralta-Tapia, A., Sponseller, R. A., Ågren, A., Tetzlaff, D., Soulsby, C., \& Laudon, H. (2015). Scale-dependent groundwater contributions influence patterns of winter baseflow stream chemistry in boreal catchments. Journal of Geophysical Research. Biogeosciences, 120(5), 847-858.

Rinaldo, A., Marani, A., \& Rigon, R. (1991). Geomorphological dispersion. Water Resources Research, 27(4), 513-525.

Santos, I. D., Fill, H. D., Sugai, M. R. V. B., Buba, H., Kishi, R. T., Marone, E., \& Lautert, L. F. (2001). Hidrometria aplicada. Curitiba: Instituto de Tecnologia para o Desenvolvimento.

Sbroglia, R. M., \& Beltrame, Â. D. V. (2012). O zoneamento, conflitos e recategorização do parque municipal da lagoa do Peri, Florianópolis/SC. Boletín Geográfico, 30(1), 5-18. http://dx.doi. org/10.4025/bolgeogr.v30i1.11542.

Schneider, V. R., \& Smoot, G. F. (1976). Development of a standard rating for the Price Pygmy current meter. Journal of Research of the U.S. Geological Survey, 4(3), 293-297.

Sidle, R. C., Tsuboyama, Y., Noguchi, S., Hosoda, I., Fujieda, M., \& Shimizu, T. (2000). Stormflow generation in steep forested headwaters: a linked hydrogeomorphic paradigm. Hydrological Processes, 14(3), 369-385.

Smoot, G. F., \& Carter, R. W. (1968). Are individual current meter ratings necessary? American Society of Civil Engineers. Journal of the Hydraulics Division, 94(2), 391-397.

Uchida, T., \& Asano, Y. (2010). Spatial variability in the flowpath of hillslope runoff and streamflow in a meso-scale catchment. Hydrological Processes, 24(16), 2277-2286.

Universidade Federal de Santa Catarina - UFSC. (2018). Mapa geológico da Ilha de Santa Catarina. Florianópolis. Retrieved in 2020, August 27, from http://lmo.ufsc.br/mapa-geologico-da-ilha-desanta-catarina/

Van Loon, A. F., Van Huijgevoort, M. H. J., \& Van Lanen, H. A. J. (2012). Evaluation of drought propagation in an ensemble mean of large-scale hydrological models. Hydrology and Earth System Sciences, 16(11), 4057-4078.

Walther, B. A., \& Moore, J. L. (2005). The concepts of bias, precision and accuracy, and their use in testing the performance of species richness estimators, with a literature review of estimator performance. Ecography, 28, 815-829.

West, M. J. (1999). Stereological methods for estimating the total number of neurons and synapses: issues of precision and bias. Trends in Neurosciences, 22(2), 51-61.

White, A. B., Kumar, P., Saco, P. M., Rhoads, B. L., \& Yen, B. C. (2004). Hydrodynamic and geomorphologic dispersion: scale effects in the Illinois River Basin. Journal of Hydrology, 288(3-4), 237-257.

Wohl, E., Barros, A., Brunsell, N., Chappell, N. A., Coe, M., Giambelluca, T., Goldsmith, S., Harmon, R., Hendrickx, J. M. H., Juvik, J., McDonnell, J., \& Ogden, F. (2012). The hydrology of the humid tropics. Nature Climate Change, 2(9), 655-662.

Wondzell, S. M., Gooseff, M. N., \& McGlynn, B. L. (2007). Flow velocity and the hydrologic behavior of streams during baseflow. Geophysical Research Letters, 34(24), 1-5.

Woods, R., Sivapalan, M., \& Duncan, M. (1995). Investigating the representative elementary area concept: an approach based on field data. Hydrological Processes, 9(3-4), 291-312.

\section{Authors contributions}

Camyla Innocente dos Santos: Conceptualization, methodology, formal analysis, investigation, data curation and writing - original draft preparation, reading and agreed to the published version of the manuscript.

Pedro Luiz Borges Chaffe: Conceptualization, methodology and writing - original draft preparation.

Alondra Beatriz Alvarez Perez: Conceptualization, methodology and investigation, reading and agreed to the published version of the manuscript.

Pedro Ferreira Arienti: Investigation, reading and agreed to the published version of the manuscript.

João Henrique Macedo Sá: Investigation, reading and agreed to the published version of the manuscript.

Editor-in-Chief: Adilson Pinheiro

Associated Editor: Fernando Mainardi Fan 